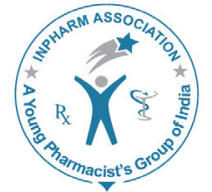

\title{
In Silico Screening, Synthesis and Pharmacological Screening of Quinazolinones Containing Oxazepinone Ring as NMDA Receptor Antagonists for Anticonvulsant Activity: Part -I
}

\author{
Megha Sahu ${ }^{1}$, Amit G. Nerkar”, Hemant U.Chikhale ${ }^{1}$, Sanjay D. Sawant ${ }^{1}$ \\ ${ }^{1}$ Department of Pharmaceutical and Medicinal Chemistry, STES's Smt. Kashibai Navale College of \\ Pharmacy, Kondhwa budhrukh, Pune-48, M.S. India
}

\begin{abstract}
Background: NMDA receptor specifically NR2B subunit plays a major role in eliptogenisis. Antagonists at NR2B receptor site have importance in design of anticonvulsant agents. Some quinazolinones and oxazepine have inherent drug likeliness for anticonvulsant activity. In this research work in silico biological activity spectrum (BAS), ADME prediction, Log P predictions and docking was carried out. A library of quinazolinones with oxazepinone ring was designed, from this library 3-(6-halo-2-methyl-oxoquinazolin-3-(4H-yl)-2-(substituted phenyl)-2, 3-dihydro-1,3-oxazepine-4,7-dione (AMQ $\left.{ }_{1-5}\right)$ were prioritized for actual synthesis and pharmacological screening for NMDA receptor antagonistic activity. Method: The prioritized molecules were synthesized and characterized by melting point, IR, ${ }^{1} \mathrm{H}-\mathrm{NMR}, \mathrm{TLC}$ and elemental analysis. AOT was performed to determine $\mathrm{LD}_{50}$ of prioritized molecules, further compounds were evaluated for their in vivo antagonistic activity on NMDA induced convulsions in mice. Result: Prioritized molecules $\mathrm{AMQ}_{1-5}$ exhibited potent antagonistic activity on NMDA receptor. Conclusion: The compound of series $A M Q_{1}$ and $A M Q_{5}$ were showed significant activity compared to standard memantine used in the assay.
\end{abstract}

Key Words: In silico, NMDA receptors, Anticonvulsant activity, Quinazolinone, Oxazepinone, Docking.

\begin{tabular}{|c|c|}
\hline \multicolumn{2}{|c|}{ Access this article online } \\
\hline Journal Sponsor & \multirow[b]{2}{*}{$\begin{array}{l}\text { Website: } \\
\text { www.jyoungpharm.org }\end{array}$} \\
\hline & \\
\hline & $\begin{array}{l}\text { DOI: } \\
\text { 10.5530/jyp.2015.1.5 }\end{array}$ \\
\hline
\end{tabular}

\section{INTRODUCTION}

A library of quinazolinone with oxazepinone ring was in silico screened for biological activity spectrum and partition coefficient predictions (Log P) using PASS server and mol inspiration software respectively. This gave biological

*Address for correspondence:

Dr. Amit G. Nerkar, Associate Professor in Medicinal Chemistry, Department of Pharmaceutical and Medicinal Chemistry, STES's Smt. Kashibai Navale College of Pharmacy, Kondhwa budhrukh, Pune-48, M.S. India. Email: amit.nerkar@sinhgad.edu

Journal of Young Pharmacists Vol 7 • Issue $1 \bullet$ Jan-Mar 2015 
Table 1: Prioritization of molecules (biological activity scores, pLog P) from the series $\mathrm{AMQ}_{1-5}$

\begin{tabular}{|c|c|c|c|c|c|}
\hline Code for comp. & $\log P^{*}$ & BAS $^{\star}$ activity & $\begin{array}{l}\text { MDCK }^{+++} \text {cell } \\
\text { permeability }\end{array}$ & $\begin{array}{l}\mathrm{CaCO}^{++} \text {cell } \\
\text { permeability }\end{array}$ & PPB $\$$ \\
\hline Memantine & 3.50 & 0.890 & 0.0076 & 25.89 & 98.89 \\
\hline $\mathrm{AMQ}_{1}$ & 3.40 & 0.554 & 0.054 & 24.83 & 93.87 \\
\hline $\mathrm{AMQ}_{2}$ & 3.41 & 0.444 & 0.069 & 18.63 & 96.61 \\
\hline $\mathrm{AMQ}_{3}$ & 2.99 & 0.331 & 0.064 & 18.75 & 97.85 \\
\hline $\mathrm{AMQ}_{4}$ & 3.87 & 0.336 & 0.141 & 23.88 & 92.10 \\
\hline $\mathrm{AMQ}_{5}$ & 3.11 & 0.235 & 0.075 & 23.52 & 95.42 \\
\hline
\end{tabular}

${ }^{++} \mathrm{CacO}_{2}$ cell permeability = human colon adenocarcinoma and possess multiple drug transport pathways through the intestinal epithelium. ${ }^{+++}$MDCK $=$Madin-Darby canine kidney cell. ${ }^{\mathrm{S} P P B}=$ Plasma Protein Binding, $\mathrm{BAS}^{*}=$ Biological activity score.

Table 2: Ranges of BAS, pLogP, and ADME Prediction Values

Biological activity spectrum Should Be greater than 0.55

LogP Should be greater than 2

Predictions

ADME Have following ranges

Predictions

$\mathrm{CaCo}_{2}$ cells Permeability

Low

Moderate

High

\begin{abstract}
less than 4
\end{abstract}
$4 \sim 70$

more than 70
MDCK $^{\star \star *}$ cells Permeability

Low

Moderate

High less than 25

$25 \sim 500$

more than 500
BBB $^{\text {sss }}$ cells

CNS active componds (+)

More than 1

\section{(\%PPB)}

Plasma protein binding ${ }^{\circledR @ \odot ~}$

Chemicals More than $90 \%$

strongly bound

CNS inactive Less than 1 Chemicals Less than $90 \%$ compounds (-) weakly bound

"'MDCK = Madin-Darby canine kidney cell. ${ }^{\circledR}{ }^{\circledR} \mathrm{PPB}=$ Plasma Protein Binding, ${ }^{+++} \mathrm{HIA}=$ Human Intestinal Absorption, BBB ${ }^{\text {s\$ }}=$ Blood brain barrier.

activity score ${ }^{1}$ (BAS) for anticonvulsant activity for NMDA inhibition mechanism and predicted $\log \mathrm{P}$ value $(\mathrm{p} \log$ $\mathrm{P})$. Quinazolinone nucleus with oxazepinone ring was selected in this research due to its significant anticonvulsant potential-9 Docking was performed on AutoDock 1.5.3 software for screening of molecule. Synthesized molecules were evaluated by IR, ${ }^{1} \mathrm{H}-\mathrm{NMR}$, Mass spectroscopy and elemental analysis. Further synthesized prioritized molecules were evaluated for in vivo acute oral toxicity (AOT) and anticonvulsant activity. Anticonvulsant activity was established in antagonism of test compounds in NMDA induced convulsion methanistic model. Acute Oral Toxicity (AOT) was carried to determine $\mathrm{LD}_{50}$ of the prioritized molecules according to OECD guideline 425 .

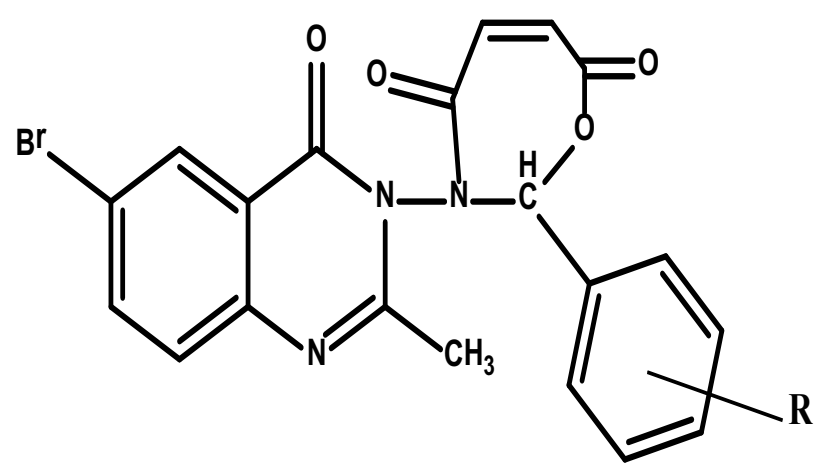

$\mathrm{R}=\mathrm{Cl}, \mathrm{Br}, \mathrm{OCH}_{3}, \mathrm{NO}_{2}$.

Figure 1: Structure of AMQ1-6 series
Further molecules were evaluated from $300-2000 \mathrm{mg} / \mathrm{kg}$ for AOT studies.

\section{MATERIALS AND METHODS}

\section{In silico screening}

Molecules were converted from 2-D chemsketch files into 3-D mol files using Marvin Sketch and then uploaded on PASS online server to get BAS prediction. Predicted Log P $(\mathrm{pLogP})$ values were obtained from molinspiration online software $^{10}$ and further ADME prediction were obtained PreADMET online server. ${ }^{11}$

BAS Activity Prediction: The compounds from the quinazolinone with oxazepinone ring $\mathrm{AMQ}_{1-5}$ series were subjected to predict BAS activity. These values are shown in Table 1, 2. Structures of these compounds are given in Figure 1.

Log $\mathrm{P}$ prediction: The ranges of $\log \mathrm{P}$ values used for prioritization are shown in Table 1, 2.

ii) $\mathrm{ADME}$ predictions ${ }^{11}$

a) MDCK cell permeability: The ranges of MDCK cell permeability used for in silico prioritization of molecule are shown in Table 2.

Journal of Young Pharmacists Vol 7 • Issue 1 • Jan-Mar 2015 
Table 3: Docking Score and Binding Energies of $A M Q_{1-5}$

\begin{tabular}{|c|c|c|c|c|c|}
\hline Compound Code & $\begin{array}{l}\text { Binding energy ( } \mathrm{k} / \\
\text { cal mol) }\end{array}$ & Docking score (k/cal mol) & $\begin{array}{l}\text { Electrostatic energy } \\
\text { (k/cal mol) }\end{array}$ & Amino Acid & H bonding \\
\hline $\begin{array}{l}\text { Standard } \\
\text { (Memantine) }\end{array}$ & -12.09 & -13.63 & -0.67 & No & No \\
\hline $\mathrm{AMQ}_{1}$ & -11.04 & -12.21 & -0.03 & ILE335:N & 1 \\
\hline $\mathrm{AMQ}_{2}$ & -10.65 & -10.56 & 1.26 & $\begin{array}{l}\text { LEU135:N } \\
\text { GLN110:NE2 }\end{array}$ & 2 \\
\hline $\mathrm{AMQ}_{3}$ & -12.40 & -12.55 & -0.05 & PHE113:N & No \\
\hline $\mathrm{AMQ}_{4}$ & -11.74 & -10.56 & -0.67 & GIN110:NE2 & 1 \\
\hline $\mathrm{AMQ}_{5}$ & -12.21 & -13.15 & 0.0 & No & No \\
\hline
\end{tabular}

Table 4: Anticonvulsant activity of $A M Q_{1}$ and $A M Q_{5}$ compound

\begin{tabular}{llll}
\hline Compound & Dose $(\mathbf{m g} / \mathbf{k g})$ & $\begin{array}{l}\text { Death (minutes) mean } \\
\pm \text { SEM }\end{array}$ & $\%$ potency \\
\hline $\mathrm{NMDA}$ & $125 \mathrm{mg} / \mathrm{kg}$ & $4.053 \pm 0.01$ & 42.45 \\
$\mathrm{AMQ}_{1}$ & $100 \mathrm{mg} / \mathrm{kg}$ & $5.776 \pm 0.60^{\cdots *}$ & 60.50 \\
$\mathrm{AMQ}_{1}$ & $200 \mathrm{mg} / \mathrm{kg}$ & $6.790 \pm 0.52^{\cdots *}$ & 71.12 \\
$\mathrm{AMQ}_{1}$ & $400 \mathrm{mg} / \mathrm{kg}$ & $6.907 \pm 0.64^{\cdots *}$ & 72.34 \\
$\mathrm{AMQ}_{5}$ & $100 \mathrm{mg} / \mathrm{kg}$ & $7.512 \pm 0.27^{\cdots *}$ & 78.68 \\
$\mathrm{AMQ}_{5}$ & $200 \mathrm{mg} / \mathrm{kg}$ & $8.173 \pm 0.39^{\cdots *}$ & 85.60 \\
$\mathrm{AMQ}_{6}$ & $400 \mathrm{mg} / \mathrm{kg}$ & $7.870 \pm 0.33^{\cdots *}$ & 82.43 \\
\hline
\end{tabular}

Each value represents the mean \pm SEM : Significance level $p * " * 0.001$

c) Blood Brain Barrier Penetration (BBB): The values of blood brain barrier predictions are shown in Table 1, 2 .

d) Plasma Protein Binding (PPB): The values are shown in Table 1, 2.

\section{Docking protocol}

Computer-assisted simulated docking experiments were carried out in Auto Dock Tools 1.5.4 for prioritized molecules. Validation of protein subunit was done by the online server www.nihserver.mbi.ucla.edu/SAVES. The ChemOffice software was used to draw molecular structures and for the conversion of the $2 \mathrm{D}$ structure to
3D mol files.

Selection of the Protein File

For the docking purpose the PDB file 3QEL was selected after evaluating several files from the Protein Database bank www.rcsb.org. (Table 3)

\section{Structure Validation of the Enzyme}

The errata report, Ramachandran plot \& mol probidity ramachandran plot was obtained from the NIH MBI sever for evaluation of protein structures and are given in Figure 2, Figure 3 and Figure 4.

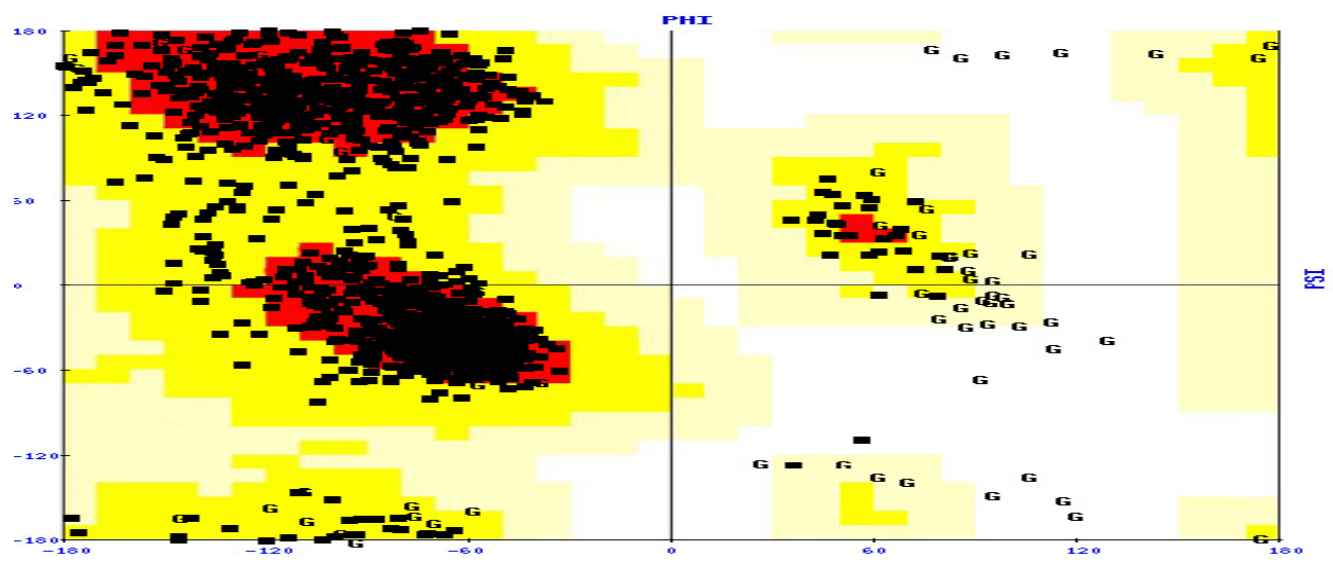

Figure 2: Ramachandran plot 
Program: ERRAT2

Chain\#:1

Overall quality factor**: 93.866

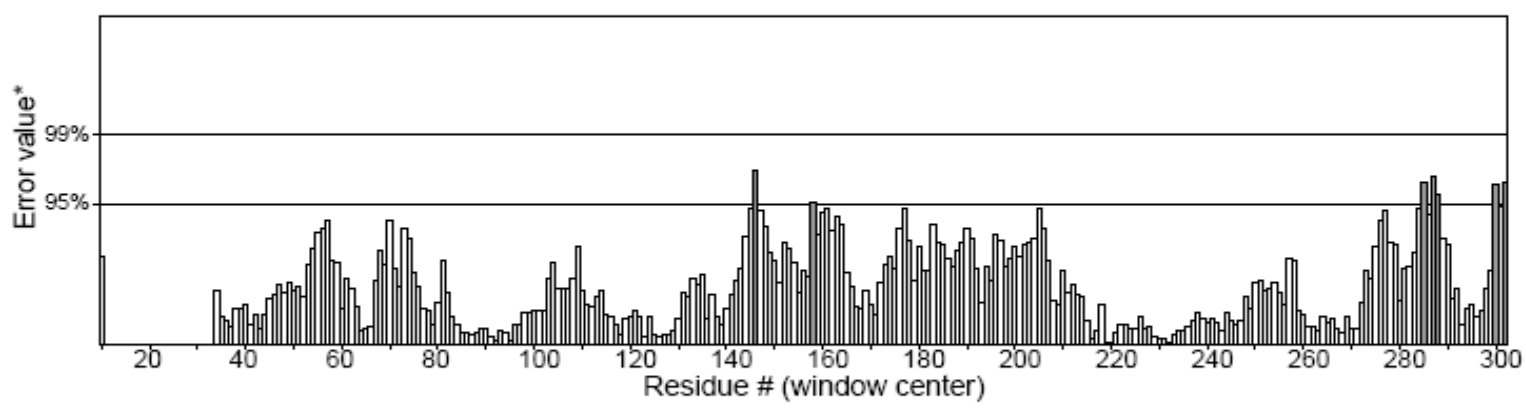

"On the error axis, two lines are drawn to indicate the confidence with
which it is possible to reject regions that exceed that error value.
"Expressed as the percentage of the protein for which the calculated
error value falls below the $95 \%$ rejection limit Good high resolution
structures genera $y$ produce values around $95 \%$ or higher. For lower
resolutions $(2.5$ to $3 \mathrm{~A}$ ) the average overall quality factor is around $91 \%$

Figure 3: Errata Report of PDB 3QEL

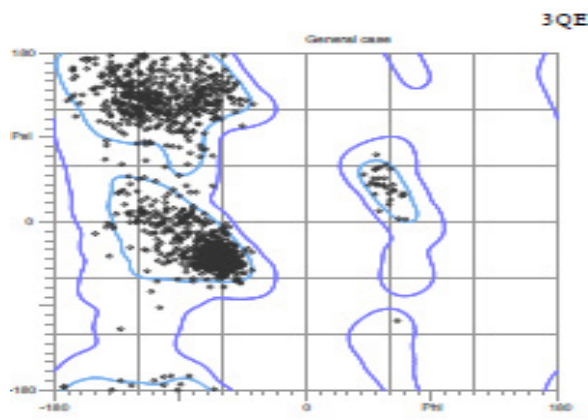

QEL, model
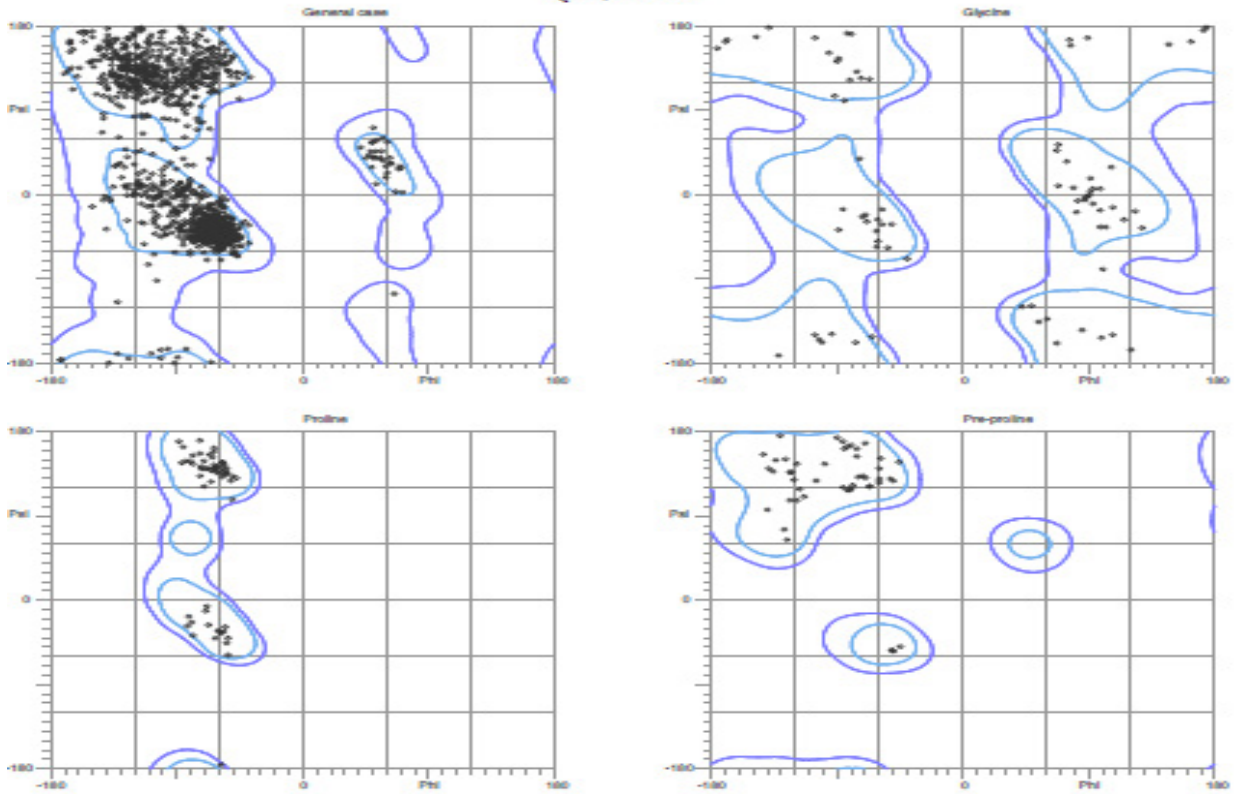

$95.5 \%(1312 / 1374)$ of all residues were in favoured (98\%) regions. $100.0 \%(1374 / 1374)$ of all residues were in allowed (>99.8\%)

Figure 4: Favoured region for binding of molecule with receptor

\section{Chemistry}

\section{General procedure for synthesis of the target compound $\left(A M Q_{1-5}\right.$ series $)$}

All chemicals were purchased from Sigma Aldrich, SD Fine, Spectrochem and Merck. Yields refer to purified products and are not optimized

\section{Synthesis of Schiff bases $^{12-20}$}

A mixture of 0.01 mole of 3-amino-2-methylquinazolin$4(3 \mathrm{H})$-one and 0.01 mole of aldehyde in $(10 \mathrm{ml})$ absolute ethanol was refluxed in water bath for $(30 \mathrm{~min})$ then left to cool in ice -water. The solid was filtered, washed with $2 \% \mathrm{HCl}$ and water. Recrystallized the precipitate twice from ethanol. Figure 1

Journal of Young Pharmacists Vol 7 • Issue 1 • Jan-Mar 2015 
<smiles>[X]c1ccc2nc(C)n(N)c(=O)c2c1</smiles>

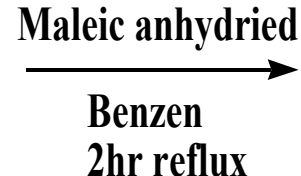

3-amino-2-methylquinazolin-4(3H)-one

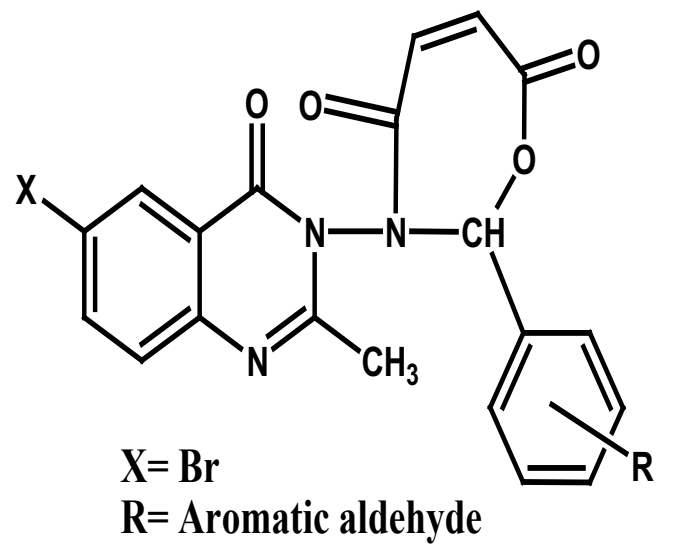

Figure 5: Synthetic scheme for $A M Q_{1-5}$

Cyclization of Schiff base (Synthesis of (Z)-2(3-hydroxyphenyl)-3-(2-methyl-4-oxoquinazolin3(4H)-yl)-2,3-dihydro-1,3-oxazepine-4,7-dione) Mixture of 0.01 mole of Schiff base ((E)-3-(3hydroxybenzylideneamino)-2 methylquinazolin- $4(3 \mathrm{H})-$ one) with 0.01 mole of maleic anhydride in $10 \mathrm{~mL}$ of dry benzene was refluxed on water bath for 2 hours. Solvent was evaporated in reduced pressure on rotatory evaporator. Remained separated solid was recrystallized using THF. Figure 5

Yield: $52.17 \%$, m.p. $206-208^{0} \mathrm{C}$. IR $\left(\mathrm{KBr}, \mathrm{cm}^{-1}\right): 1690$ (C=O str. Of quinazolinone), 1598 ( $\mathrm{N}-\mathrm{C}=\mathrm{O}$ str.), 1342, 1476, 2900, (-CH str. of hetero aromatic ring), 1600 ( $\mathrm{C}=\mathrm{C}$ str. Aromatic), 604-700 (C-Cl, C-Br str. Of chlorophenyl, quinazolinone respectively). ${ }^{1} \mathrm{H}-\mathrm{NMR}\left(300 \mathrm{MHz}, \mathrm{CDCl}_{3}\right.$ shift in ppm): 9.6-9.65 (s, 1H, N-CH of oxazepine), 8.48.45(s, $1 \mathrm{H}, \mathrm{CH}$ of quinazolinone), 7.45-7.6 (d, J=8.7Hz $, 2 \mathrm{H}, \mathrm{CH}$ of quinazolinone), $7.8(\mathrm{~d}, \mathrm{~J}=2.4,2 \mathrm{H}),, 7.4(\mathrm{t}, \mathrm{J}=9$, $1 \mathrm{H}), 6.4-6.8(\mathrm{~d}, \mathrm{~J}=7.2,2 \mathrm{H}$, vinylic proton of oxazepine), 1.32 (s, 3H, methyl of quinazoline). Anal. Calcd for $\mathrm{C}_{20} \mathrm{H}_{12} \mathrm{O}_{4} \mathrm{~N}_{3} \mathrm{BrCl}_{2}$ : C, 47.18\%; H, 2.38\%; N, 8.25\%; O, $12.57 \%$. Found: C, $47.20 \%$; H, 2.36\%; N, 8.23\%; O, $12.6 \%$.

3-(6-bromo-methyl-oxoquinazolin-3(4H)-yl)-2(4-nitrophenyl)-2,3-dihydro-1,3-oxazepine-4, 7dione. $\left(\mathrm{AMO}_{2}\right)$

Yield: $46.83 \%$, m.p. $200-202^{0} \mathrm{C}$. IR $\left(\mathrm{KBr}, \mathrm{cm}^{-1}\right): 1677$ (C=O Str. of quinazolinone), 1640 (C=N str.), 1342, 1476, 1349, 1400, 2985, 3057, 3012.4 (-CH str. of hetero aromatic ring), 1600 (C=C str. Aromatic); ${ }^{1} \mathrm{H}-\mathrm{NMR}$ (shift in ppm) 9.45 (s, $1 \mathrm{H}, \mathrm{N}-\mathrm{CH}$ of oxazepine), $8.2-8.4(\mathrm{~d}, \mathrm{~J}=8.7 \mathrm{~Hz}, 2 \mathrm{H}, \mathrm{CH}$ of quinazolinone), 7.6-7.8(m, 4H, CH of aromatic), 6.4-6.6 (d, J $=12.3,2 \mathrm{H}$, vinylic proton of oxazepine), 1.25 (s, $3 \mathrm{H}$, methyl of quinazoline). Anal. Calcd for $\mathrm{C}_{20} \mathrm{H}_{13} \mathrm{O}_{6} \mathrm{~N}_{4} \mathrm{Br}$ : C, $49.50 \% ; \mathrm{H}, 2.70 \%$; N , 11.55\%; O, 19.78. Found: C, 49.53\%; $\mathrm{H}, 2.68 \%$; N, $11.50 \% ; \mathrm{O}, 19.75 \%$.

Journal of Young Pharmacists Vol 7 • Issue 1 • Jan-Mar 2015
3-(6-bromo-methyl-oxoquinazolin-3(4H)-yl)-2-(4bromophenyl)-2, 3-dihydro-1, 3-oxazepine-4, 7dione. $\left(\mathrm{AMO}_{3}\right)$

Yield: 52.84\%, m.p. $196-198^{\circ} \mathrm{C}$. IR $\left(\mathrm{KBr}, \mathrm{cm}^{-1}\right): 1677(\mathrm{C}=\mathrm{O}$ str. of quinazolinone), 1597 (C=N str.), 1327, 1470, 1349, 2960, 2985, 3012.4 (-CH str. of hetero aromatic ring), 1640 (C=N str.). ${ }^{1} \mathrm{H}-\mathrm{NMR}$ (shift in $\mathrm{ppm}$ ): 9.6 (s, $1 \mathrm{H}$, $\mathrm{N}-\mathrm{CH}$ of oxazepine), 8.8 (s, $1 \mathrm{H}, \mathrm{CH}$ of quinazolinone ), $7.8(\mathrm{~d}, \mathrm{~J}=9.3 \mathrm{~Hz}, 2 \mathrm{H}), 7.4(\mathrm{~d}, \mathrm{~J}=8.7 \mathrm{~Hz}, 2 \mathrm{H}, \mathrm{CH}$ of quinazolinone), 7.45-7.6(d, J=9, $2 \mathrm{H}$, quinazolinone), 6.4-6.6 (d, $\mathrm{J}=12,2 \mathrm{H}$, vinylic proton of oxazepine), 1.32 (s, $3 \mathrm{H}$, methyl of quinazoline). Anal. Calcd for $\mathrm{C}_{20} \mathrm{H}_{13} \mathrm{O}_{4} \mathrm{~N}_{3} \mathrm{Br}_{2}$ : C, 46.27\%; H, 2.52\%; N, 8.09\%; O, 12.33\%. Found: C, $46.25 \%$; H, 2.50\%; N, 8.12\%; O, $12.36 \%$.

3-(6-bromo-methyl-oxoquinazolin-3(4H)-yl)-2(2-nitrophenyl)-2,3-dihydro-1,3-oxazepine-4,7dione. $\left(\mathrm{AMO}_{4}\right)$

Yield: $43.23 \%$, m.p. $186-188^{\circ} \mathrm{C}$. IR $\left(\mathrm{KBr}, \mathrm{cm}^{-1}\right): 1677(\mathrm{C}=\mathrm{O}$ str. Of quinazolinone), 1597 (C=N str.), 1327, 1470, 1349, 2960, 2985, 3012.4 (-CH str. of hetero aromatic ring), 1640 (C=N str.) ${ }^{1} \mathrm{H}-\mathrm{NMR}$ (shift in ppm): 9.2 (s, 1H, $\mathrm{N}-\mathrm{CH}$ of oxazepine), 8.0 (s, $1 \mathrm{H}, \mathrm{CH}$ of quinazolinone ), $7.8(\mathrm{~d}, \mathrm{~J}=1.8 \mathrm{~Hz}, 2 \mathrm{H}), 7.4(\mathrm{t}, \mathrm{J}=15 \mathrm{~Hz}, 14.7 \mathrm{~Hz}, 1 \mathrm{H}, \mathrm{CH}$ of quinazolinone), 7.45-7.6 (d, $\mathrm{J}=7.8,2 \mathrm{H}$, quinazolinone), 6.4-6.8 (d, J=12.3, $2 \mathrm{H}$, vinylic proton of oxazepine), 1.56 (s, $3 \mathrm{H}$, methyl of quinazoline). Anal. Calcd for $\mathrm{C}_{20} \mathrm{H}_{12} \mathrm{O}_{6} \mathrm{~N}_{4} \mathrm{Br}$ : C, 49.50\%; H, 2.70\%; N, 11.55\%; O, 19.78\%. Found: C, $49.52 \% ; \mathrm{H}, 2.72 \%$; N $11.53 \% ; \mathrm{O}, 19.76 \%$.

3-(6-bromo-methyl-oxoquinazolin-3(4H)-yl)-2-(4methoxyphenyl)-2,3-dihydro-1,3-oxazepine-4, 7dione. $\left(A M Q_{5}\right)$

Yield: $48.42 \%$, m.p. $192-194{ }^{\circ} \mathrm{C}$ IR $\left(\mathrm{KBr}, \mathrm{cm}^{-1}\right): 1600(\mathrm{C}=\mathrm{C}$ str. aromatic), 1677 ( $\mathrm{C}=\mathrm{O}$ str. Of quinazolinone), 1597 (C=N str.), 1347, 1467, 2985, 3020 (-CH str. of hetero aromatic ring) ${ }^{1} \mathrm{H}-\mathrm{NMR}$ ( shift in ppm ): 8.9 (s, $1 \mathrm{H}, \mathrm{N}-\mathrm{CH}$ 
of oxazepine), 8.4 (s, 1H, CH of quinazolinone), 7.6-7.89 (d, $\mathrm{J}=7.5,2 \mathrm{H}$, quinazolinone), $7.2(\mathrm{~d}, \mathrm{~J}=9 \mathrm{~Hz}, 2 \mathrm{H}), 7.0(\mathrm{~d}$, $\mathrm{J}=9 \mathrm{~Hz}, 1 \mathrm{H}, \mathrm{CH}$ of quinazolinone), 6.4-6.8 (d, $\mathrm{J}=12.3$, $2 \mathrm{H}$, vinylic proton of oxazepine), $3.8\left(\mathrm{~s}, 3 \mathrm{H}, \mathrm{OCH}_{3}\right.$ of phenyl ring), 1.25 (s, $3 \mathrm{H}$, methyl of quinazoline). Anal. Calcd for $\mathrm{C}_{20} \mathrm{H}_{16} \mathrm{O}_{5} \mathrm{~N}_{3} \mathrm{Br}$ : C, $49.50 \% ; \mathrm{H}, 2.70 \% ; \mathrm{N}, 11.55 \%$; O, 19.78\%. Found: C, 49.52\%; H, 2.72\%; N, 11.53\%; O, $19.76 \%$.

\section{Pharmacological screening}

Swiss albino mice of either sex weighing between 20-25 gm, obtained from National Toxicological Centre, Pune, India. During the course of the experiment, the general behaviour of the animal was normal. ${ }^{21-24}$ To ensure proper testing, prior to the testing for $24 \mathrm{hr}$ period mice had free access to food and water. All the experimental protocols were approved by the institutional animal ethical committee according to OECD guidlines $425 .^{21}$

\section{Acute Oral Toxicity (AOT) Studies}

AOT studies were performed to determine the $\mathrm{LD}_{50}$ of the compounds following the OECD 425 guidelines. According to OECD guidelines the dose should be 300 $2000 \mathrm{mg} / \mathrm{kg}$ for AOT study. ${ }^{22}$ Animal were observed for 4 $\mathrm{hr}$ and also observed for salivation, lacrimation and motor activity of animals. Further animals were observed for 24 $\mathrm{hr}$ and note the death rate of animals.

\section{Antagonism of NMDA induced convulsions (Anticonvulsant Activity)}

Six mice of either sex with a weight of 20 to $25 \mathrm{~g}$ were treated with test compound or the standard (Memantine) by oral or subcutaneous administration. Controls received the vehicle only 30 minutes after subcutaneous (s. c.) or 60 minutes after p.o treatment the animals were injected with subcutaneous dose of $125 \mathrm{mg} / \mathrm{kg}^{23,24}$ NMDA (N-methylD-aspartate). During the next 120 minutes the occurrence of clonic seizures, tonic seizures \& death was recorded at dose levels of the test $100 \mathrm{mg} / \mathrm{kg}$ to $4000 \mathrm{mg} / \mathrm{kg}$. Test group received synthesized (test) compounds $\left(\mathrm{AMQ}_{1-5}\right)$. Standard group received Memantine $10 \mathrm{mg} / \mathrm{kg}$. (Table 4)

\section{RESULT AND DISCUSSION}

In silico study was performed by Biological activity prediction Spectrum (BAS), Log P, Auto dock tool 1.5.4 and Pre ADMET software. Novel series of 4-OxoQuinazolines with oxazepinone $\left(\mathrm{AMQ}_{1-5}\right)$ ring showed the interaction with ILE335:N, GLN110:NE2, PHE113:N and GIN110:NE2. AMQ $1, \mathrm{AMQ}_{2}$ and $\mathrm{AMQ}_{3}$ molecules showed good hydrogen bonding with receptor. In general the obtained scores are in between -10.5 and -15.56 and compared with standard Memantine with the score of -13.63. All the ligands docked deeply within the binding pocket region suggested their shape complementarily with 3QEL. LogP values are between 2.99 to 3.87 suggested that prioritized molecules can cross Blood brain barrier (BBB). Further synthesized compounds of series $A M Q_{1-5}$ were evaluated for pharmacological screening by acute oral toxicity (AOT) and anticonvulsant activity on NMDA receptor by mechanistic model. AOT was carried at a dose of $300-2000 \mathrm{mg} / \mathrm{kg}$ on mice for determining the $\mathrm{LD}_{50}$ of compounds based on OECD 425 guidelines. On the basis of AOT (shown in table) the dose for anticonvulsant activity was chosen between $50-400 \mathrm{mg} / \mathrm{kg}$. Compound $\mathrm{AMQ}_{1}$ and $\mathrm{AMQ}_{5}$ showed $60.5 \%$ and $85 \%$ of percentage potency respectively as compared with Memantine taken as standard in the anticonvulsant pharmacological screening.

\section{CONCLUSION}

Compounds $\mathrm{AMQ}_{1}$ and $\mathrm{AMQ}_{5}$ can serve as lead for as NMDA receptor antagonists for anticonvulsant activity.

\section{ACKNOWLEDGEMENT}

We acknowledge the Board College and University Development (BUCD), University of Pune, India for funding the project vide sanction number 13PHM000882.

\section{CONFLICTS OF INTEREST}

Authors declare none conflicts of intrests

\section{REFERENCES}

1. http://195.178.207/pass/2008/en/online/predict.ph

2. Raj V, Rai A, Rawat JK. In silico design and computational study of novel 1, 3, 4-thiadiazole derivatives as potential affinity with $\mathrm{Na} / \mathrm{H}$ exchanger receptor for anticonvulsant activity. Pharma tutor. 2014; 2(5): 113-9.

3. Loscher W. New visions in the pharmacology of anticonvulsion. Eur. J. Pharmacol. 1998; 342(1): 1-13.

4. Porter RK, Penry JK, Meinardi H, Rowan AJ. Advances in Epileptology: Psychology, Pharmacotherapy and new Diagnostic Approaches, Amsterdam. Netherlands. 1978; 4(2): 220.

5. Gallagher BB, Vida JA. Anticonvulsants, Academic, New York; 1977. 11.

6. Brodie MJ. Status epilepticus in adults, Lancet. 1990; 336(8714): 551-2.

7. Wolfe JF, Rathman TL, Sleevi MC. Synthesis and anticonvulsant activity of some new 2-substituted 3-aryl-4(3H)-quinazolinones. J. Med. Chem. 1990; 33(1):161-6.

8. Bahekar RH, Rao ARR. Synthesis, evaluation and structure activity relationships of 5- alkyl-2,3-dihydroimidazo[1,2-c]quinazoline, 2,3-dihydroimidazo[1,2-c]quinazolin$5(6 \mathrm{H})-12$ thiones and their oxo-analogues as new potential bronchodilators. Arzneim.Forsch. Drug Res. 2001; 5(1):284.

9. www.lce.hut.fi/teaching/S-114.500/2002/Protdock.pdf. Available from: http://www.csc. /lehdet/atcsc/atcsc2-2002/atcsc2 02.pdf.

10. www.molinspiration.com

11. www.preadmet.com

12. Sharma NK, Jha KK. Molecular Docking: An overview. J. Adv.Sci.Res. 2010; 1(1):67-72. 
13. Mondal P, Banerjee M, Jana S and Bose A. Synthesis and evalution of 1, 3-di substituted schiffs base, mannich base and spiro isatin derivatives. J Young Pharm. 2010; 2(2): 169-72.

14. Laddha SS, Bhatnagar SP. Rapid microwave-assisted solution phase synthesis of 6, 8-disubstituted- 2-phenyl-3-(substituted-benzothiazole-2-yl) - 4-[3H]quinazolinone as novel anticonvulsants. Proceedings of the $10^{\text {th }}$ International Electronic Conference on Synthetic Organic Chemistry (ECSOC-10). 1-30 November; 2006.

15. Sharma G, Park JY, Park MS. Design and synthesis of 6-amino-1, 4-oxazepane-3, 5 -dione derivatives as novel broad spectrum anticonvulsants. Bioorg. Med. Chem. Lett. 2008; 18(11): 3188-91.

16. Bayati RIA, Amiery AAH, Majedy YK. Researcher, 2010; 2(4): 82-8.

17. Mishra P, Gupta PN, Shakya AK. Synthesis of some Schiff Bases of 3-Amino2-Methylquinazolin-4(3H)-ones and Their Antimicrobial Activities. J. Ind. Chem. Soc. 1991; 68(11): 618-9.

18. Revanasiddappa HD, Prasad KS, Kumar LS, Jayalakshmi B. Synthesis and Biological Activity of New Schiff Bases Containing 4(3H)-Quinazolinone Ring System. Int. J. ChemTech Res. 2010; 2(2): 1344-9.
19. Moreau JL, Pieri L, Prud'hon B. Convulsions induced by centrally administered NMDA in mice: effects of NMDA antagonists, benzodiazepines, minor tranquilizers and anticonvulsants. Br. J. Pharmacol. 1989; 98(3): 1050-4

20. Gaoni Y, Chapman AG, Parvez N, Pook CK, Jane DE, Watkins JC Synthesis, NMDA receptor antagonist activity, and anticonvulsant action of 1-aminocyclobutanecarboxylic acid derivatives. J. Med. Chem. 1994; 37(25): 4288-96.

21. OECD Guideline for testing of chemical, Adopted: 2001 December 17.

22. Parasuraman S. Toxicological screening. J Pharmcol Pharmacother. 2011; 2(2): 74-9.

23. Laddha SS, Wadokar SG, Meghal SK. Studies on some biologically active substituted 4(3H)-Quinazolinone: Part.1. Synthesis, Characterization and Antiinflammatory- Antimicrobial activity of 6,8 disubstituted, 2-phenyl-3-[substitutedbenzothiazole-2-yl]- 4[3H]-quinazolinone. Arkivocxi, 2006; 1-20.

24. Nerkar AG, Chikhale HU, Joshi PP, Kudale SA, Lade KS, Sawant SD. In silico Design, Synthesis \& Pharmacological Screening of Some Quinazolinones as Possible GABAA Receptor Agonists for Anticonvulsant Activity. Int. J. Pharm. Pharm Sci. 2012; 4(2): 466-9. 